\title{
PENGEMBANGAN LEMBAR KERJA PESERTA DIDIK BERBASIS ETNOSAINS DENGAN MODEL PENALARAN KAUSAL UNTUK MEMECAHKAN MASALAH
}

\author{
Satriani, Rafiqah, Muh. Syihab Ikbal \\ Pendidikan Fisika Fakultas Tarbiyah dan Keguruan UIN Alauddin Makassar, Satriani_061795@yahoo.co.id.
}

\begin{abstract}
Abstrak
Jenis penelitian ini adalah Research and Development ( $R \& D)$ yang bertujuan mengetahui proses pengembangan LKPD dan kevalidan serta reabilitas, kefektifan LKPD Berbasis Etnosains dengan Model Penalaran Kausal terhadap hasil belajar peserta didik. Lokasi penelitian di SMPN 1 Pangkaje $\square$ ne Kab. Pangkep kelas VIII D yang berjumlah 35 peserta didik semester ganjil 2016/2017. Komponen LKPD yang dikembangkan dalam penelitian ini adalah isi LKPD. Model Pengembangan LKPD yang digunakan adalah mengacu pada model 4-D, yaitu pendefinisian, perancangan, pengembangan, dan penyebaran. Instrumen penelitian yang digunakan adalah lembar validasi aspek-aspek LKPD, angket respon peserta didik dan tes hasil belajar.Data yang diperoleh dianalisis secara deskriptif. Hasil analisis deskriptif yang berkaitan dengan menggunakan analisis validasi, realibilitas dan keefektifan LKPD diperoleh tingkat kevalidan dan realibilitas dengan nilai 0,7 dan 0,89 dapat dikatakan valid dan reliabel. Sedangkan tingkat kefektifan LKPD dapat dikatakan efektif karena $t_{\text {hitung }}>$ $t_{\text {tabel }}$ nilai 5,20 > 2,02 dapat meningkatkan dan memecahkan masalah pada peserta didik..
\end{abstract}

Kata kunci: Etnosains, LKPD, Penalaran Kausal.

\section{Pendahuluan}

Menurut Purwanto (2014:187) guna membantu guru dalam pengembangan lembar kerja peserta didik, perlu suatu acuan yang bersifat operasional. Acuan yang dimaksud berupa pedoman teknis yang minimal memuat prinsip-prinsip, kaidah kaidah, ketentuan ketentuan dan prosedur pengembangan lembar kerja peserta didik. Pedoman teknis perlu dirancang sedemikian rupa sehingga praktis dan menarik untuk dibaca dan digunakan oleh guru dan unsur unsur lain dalam penyusunan lembar kerja peserta didik.

Menurut Purwanto (2014:186) terkait dengan pengembangan bahan ajar, saat ini pengembangan bahan ajar dalam bentuk lembar kerja peserta didik menjadi kebutuhan yang sangat mendesak. Hal ini merupakan konsekuensi diterapkannya kurikulum tingkat satuan pendidikan berbasis kompetensi di sekolah. Kompetensi mempersyaratkan penggunaan lembar kerja peserta didik dalam pelaksanaan pembelajarannya. Modul dapat membantu sekolah dalam mewujudkan pembelajaran yang berkualitas. Penerapan lembar kerja peserta didik dapat mengkondisikan kegiatan pembelajaran lebih terencana dengan baik, mandiri, tuntas dan dengan hasil (output) yang jelas.
Pemilihan sekolah SMPN 1 Pangkaje $\square$ ne Kab. Pangkep sebagai sekolah untuk menerapkan lembar kerja peserta didik berbasis etnosains dengan model penalaran kausal untuk memecahkan masalah karena disekolah ini gurunya belum menerapkan lembar kerja yang berbasis lain. Sehingga etnosains belum digunakan dan merupakan hal yang masih baru dan untuk perkembangan selanjutnya dikarenakan etnosains, dimana hal-hal yang dianggap mitos atau pamali kemungkinan gurunya sudah meneliti akan tetapi materi materi ataupun soal-soal yang diberikan masih kurang atau mungkin adanya keterbatasan antara pemilihan soal dengan penerapannya dalam kehidupan sehari-hari. Kemudian masyarakat masyarakat disana masih kental dengan kepercayaan orang dahulu (mitos dan pamali) masih sering digunakan. Etnosains berbicara mengenai orang terdahulu dengan larangan larangan yang akan dibahas secara lebih ilmiah dan rinci, sehingga waktu yang digunakan guru untuk menelaah etnosains masih diperlukan penambahan waktu, keterbatasana waktu inilah yang menyebabkan guru kurang untuk memikirkan hal hal yang berbau etnosains.

Mengenai model yang digunakan dalam Lembar Kerja Berbasis Etnosains ini, peneliti menggunakan penalaran kausal, ada banyak macam macam penalaran akan tetapi penalaran 
yang dianggap sesuai dengan lembar kerja berbasis etnosains yaitu penalaran kausal karena dengan menalar dan menelaah dari mana sumber sumber yang ingin diteliti tentang mitos tersebut dan membandingkan secara ilmiah dalam kehidupan sehari hari sehingga kita tidak sembarangan menyebut alasan alasan yang tidak logis. Guna membandingkan atau menghubungkan mengapa disebut pamali dengan materi materi fisika yang ada dalam kehidupan sehari-hari.

Berdasarkan latar belakang diatas, aktivitas dan kreativitas yang diharapkan dalam proses pembelajaran dituntut interaksi yang seimbang, interaksi yang dimaksud adalah adanya interaksi antara guru dengan peserta didik, peserta didik dengan peserta didik, dan peserta didik dengan guru. Dalam prosesnya nanti diharapkan adanya komunikasi banyak arah yang memungkinkan aktivitas dan kreativitas yang diharapkan. Oleh karena itu penulis termotivasi untuk melakukan penelitian dengan Judul: $\square$ Pengembangan Lembar Kerja Peserta Didik (LKPD) Berbasis Etnosains dengan Model Penalaran Kausal untuk memecahkan masalah di SMPN 1 Pangkaje $\square$ ne Kab. Pangkep $\square$, dengan tujuan 1) Untuk mengembangkan Lembar Kerja Peserta Didik Berbasis Etnosains dengan Model Penalaran Kausal untuk memecahkan masalah di SMPN 1 Pangkaje $\square$ ne Kab. Pangkep; 2) Untuk menilai kevalidan dan reliabel Lembar Kerja Peserta Didik Berbasis Etnosains dengan Model Penalaran Kausal yang untuk memecahkan masalah di SMPN 1 Pangkaje $\square$ ne Kab. Pangkep; 3) Untuk mengetahui hasil belajar peserta didik setelah menggunakan Lembar Kerja Berbasis Etnosains dengan Model Penalaran Kausal untuk memecahkan masalah di SMPN 1 Pangkaje $\square$ ne Kab. Pangkep.

\section{Metode Penelitian}

Menurut Sugiono (2010) dalam Utami (2015:25) jenis penelitian yang digunakan dalam penelitian ini adalah penelitian pengembangan (Researh and Development). Subjek penelitian siswa SMPN kelas VIIID sebanyak 35 orang tahun pelajaran 2016/2017 dan dijadikan sebagai responden untuk uji coba terbatas LKPD yang dibuat. Komponen LKPD yang dikembangkan dalam penelitian ini adalah isi LKPD yang Berbasis Etnosains dengan Model Penalaran Kausal. Model Pengembangan LKPD yang digunakan dalam penelitian ini mengacu pada model 4-D. Model Pengembangan LKPD yang digunakan dalam penelitian ini mengacu pada model 4-D. Model 4-D terdiri dari pendefinisian (define), perancangan (design), pengembangan (develop), dan penyebaran (disseminate). Tahap-tahap pengembangan modul pembelajaran tersebut diuraikan sebagai berikut: 1).Tahap Pendefinisian (Define). Tujuannnya adalah menetapkan dan menentukan syarat-syarat pembelajaran yang meliputi tujuan pembelajaran dan pembatasan materi pembelajaran. Adapun langkahlangkahnya sebagai berikut: (a) Analisis awal akhir bertujuan untuk memunculkan dan menetapkan masalah dasar yang diperlukan dalam pengembangan lembar kerja peserta didik. (b) Analisis materi bertujuan untuk mengidentifikasikan bagian-bagian materi etnosains (pamali) yang memiliki kaitan hubungan ilmu dengan fisika. (c) Analisis tugas adalah kumpulan prosedur untuk menentukan isi dalam LKPD berdasarkan kajian kurikulum yang berlaku yaitu kurikulum KTSP ketika perancangan LKPD akan dilakukan. Analisis tugas dilakukan untuk merinci isi materi LKPD berbasis etnosains dalam bentuk garis besar yang mencakup; (1) Analisis struktur isi yang memaparkan tentang materi etnosains yang berkaitan dengan materi fisika, (2) analisis prosedural berkaitan dengan urutan LKPD mulai dari tujuan pembelajaran, teori singkat, hal-hal ilmu fisika yang berkaitan dengan etnosains, kesimpulan dan evaluasi/penugasan, dan (3) analisis proses informasi berkaitan dengan informasi yang terdapat dalam LKPD baik dari segi kognitif maupun psikomotorik. 2). Tahap Perancangan (Design). Pada tahap ini dihasilkan rancangan LKPD. Tahap perancangan bertujuan untuk merancang LKPD yang dikembangkan. Tahap ini merupakan tahap penting dalam penelitian karena pada tahap ini akan dikembangkan LKPD yang berbasis etnosains dengan model penalaran kausal untuk memecahkan masalah pada siswa. Langkah-langkahnya adalah sebagai berikut: (a) Pemilihan format LKPD dimaksudkan untuk mendesain atau merancang isi LKPD, baik tujuan pembelajaran yang dikembangkan serta materi dalam LKPD berbasis etnosains. (b). Rancangan awal LKPD dimaksudkan adalah rancangan LKPD yang dibuat sebelum uji coba. Rancangan awal LKPD meliputi: (1) Merancang layout LKPD. Cover LKPD dirancang menyesuaikan dengan karakter LKPD dengan judul LKPD berbasis etnosains dengan model penalaran kausal untuk memecahkan masalah pada peserta didik. (a) Isi LKPD pada bagian isi LKPD, layout dibuat menyerupai buku paket. Menggunakan perpaduan warna dari 12 warna yang ada, dengan warna warni. (2) Menyusun komponen kerangka LKPD kerangka modul disusun berdasarkan tujuan 
instruksional yang meliputi: halaman sampul, apa saja isi LKPD, sampul per-materi etnosains, pendahuluan percakapan komik, tujuan pembelajaran, kajian pustaka, cerita etnosains dan alasannya, bahan diskusi, kesimpulan dan evaluasi/penugasan. Semua LKPD yang dihasilkan pada tahap ini disebut prototype 1.3). Tahap Pengembangan (Develop). Pada tahap ini dihasilkan bentuk akhir LKPD setelah melalui revisi berdasarkan masukkan dari para ahli dan data hasil uji coba. (a). Validasi ahli Pada tahap ini meminta pertimbangan secara teoritis ahli dan praktisi tentang kevalidan prototipe-1. Validator terdiri atas ahli bidang ilmu fisika, ahli media pembelajaran, dan praktisi pendidikan. Para validator diminta untuk menvalidasi semua modul baik dari segi aspek penyajian, aspek isi atau materi serta kebahasaan yang telah dihasilkan pada tahap perancangan (prototype 1). (b).Uji coba terbatas. LKPD yang telah direvisi tersebut untuk selanjutnya diuji cobakan. Uji coba hanya dilakukan pada peserta didik SMPN 1 Pangkaje $\square$ ne untuk mendapatkan masukkan peserta didik di lapangan terhadap LKPD yang telah digunakan. Rangkaian uji coba yaitu pelaksanaan proses pembelajaran menggunakan produk dan kemudian mengobservasi peserta didik selama kegiatan proses pembelajaran berlangsung. Setelah melaksanakan kegiatan evaluasi/penugasan siswa diberikan angket tanggapan (respon) terkait dengan LKPD berbasis etnosains digunakan. Selanjutnya dilakukan revisi 2 berdasarkan data hasil uji coba dan hasilnya diperoleh modul prototype 3. 4). Tahap Penyebaran (Disseminate) Pada tahap ini merupakan tahapan penggunaan LKPD yang telah dikembangkan dan telah diuji coba pada skala yang lebih luas. Tahap penyebaran dilaksanakan untuk menguji efektifitas LKPD dalam kegiatan pembelajaran pada SMP/MTS dalam skala terbatas.

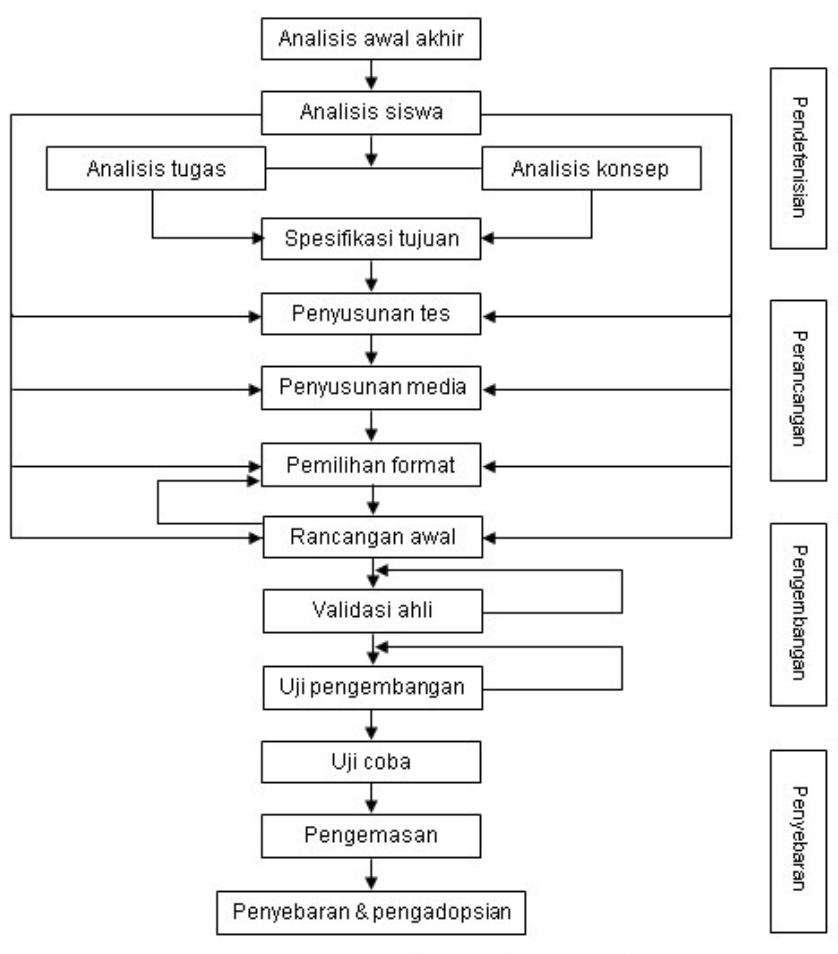

Gambar 3. Model pengembangan sistem pembelajaran 4-D

Sumber: Trianto (2010)

Gambar 1 : Model pengembangan perangkat pembelajaran 4D Thiagarajan.

Instrumen yang digunakan dalam penelitian ini adalah (1) lembar validasi; (2) angket respon siswa; dan (3) tes akhir. 1) Lembar Validasi. Seluruh lembar validasi dalam penelitian ini digunakan untuk mengukur kevalidan LKPD, dan seluruh instrumen LKPD berpatokan pada rasional teoritik yang kuat, dan konsistensi secara internal antar komponen-komponen LKPD dari segi konstruksi dan isinya. 2) Angket Respon Peserta Didik. Instrumen ini digunakan untuk memperoleh data mengenai pendapat atau komentar siswa tehadap kegiatan pelaksanaan LKPD. Disamping itu, dengan menggunakan instrumen ini ingin diketahui juga hasil belajar peserta didik untuk mengikuti kegiatan pelaksanaan LKPD. 3) Tes hasil belajar dalam penelitian ini merupakan salah satu instrumen yang digunakan dalam uji coba terbatas yang digunakan untuk menggambarkan keefektifan LKPD setelah digunakan.

Menggunakan analisis statistik deskriptif, data penelitian dapat dianalisis sebagai berikut: 1). Analisis Data Validasi Ahli untuk masing-masing LKPD dianalis dengan mempertimbangkan masukan, komentar dan saran-saran dari para validator. Hasil analisis tersebut disajikan sebagai pedoman untuk merevisi LKPD. 2).Analisis Respon peserta didik data tentang respon peserta didik diperoleh dari angket respon peserta didik terhadap LKPD yang kemudian 
membandingkan nilai rerata total skor masing-masing komponen dengan kriteria sebagi berikut:

Tabel 1: Nama-Nama Validator

\begin{tabular}{|c|c|c|c|}
\hline No & Nama & Jabatan & \\
\hline 1 & Nardin, S.Pd., M.Pd & $\begin{array}{l}\text { Dosen } \\
\text { Kesehatan } \\
\text { Kesehatan } \\
\text { Masyarakat, }\end{array}$ & $\begin{array}{l}\text { Analisis } \\
\text { Fakultas } \\
\text { UIT }\end{array}$ \\
\hline 2 & Rafiqah, S.Si., M.Pd & $\begin{array}{l}\text { Sekertari } \\
\text { Pendidikan } \\
\text { UIN } \\
\text { Makassar }\end{array}$ & $\begin{array}{r}\text { Jurusan } \\
\text { Fisika } \\
\text { Alauddin }\end{array}$ \\
\hline 3 & $\begin{array}{l}\text { Santih Anggaraeni, } \\
\text { S.Pd., M.Pd }\end{array}$ & $\begin{array}{l}\text { Dosen } \\
\text { Pendidikan } \\
\text { UIN } \\
\text { Makassar }\end{array}$ & $\begin{array}{r}\text { Jurusan } \\
\text { Fisika } \\
\text { Alauddin }\end{array}$ \\
\hline
\end{tabular}

Aspek-aspek yang di perhatikan dalam validasi LKPD secara umum adalah Aspek yang dinilai meliputi; (1) Penyajian, (2) Kelayakan isi, dan (3) Kebahasaan. Hasil analisis tersebut disajikan sebagai pedoman untuk merevisi LKPD. Untuk mengetahui kesepakatan ini, dapat digunakan indeks validitas, diantaranya dengan indeks yang diusulkan oleh Aiken (1980;1985; Kumaidi,2014). Indeks validitasi butir yang disusulkan Aiken ini dirumuskan sebagai berikut:

Dari hasil perhitungan indeks $\mathrm{V}$, suatu butir atau perangkat dapat dikategorikan berdasarkan indeksnya.

Tabel 2: Tingkat kolerasi dan kekuatan hubungan.

\begin{tabular}{ccc}
\hline NO & Rentang Indeks & Kategori \\
\hline 1 & $\mathrm{~V} \leq 0,4$ & Kurang valid \\
2. & $0,4<\mathrm{V} \leq 0,8$ & Valid \\
3. & $0,8<\mathrm{V} \leq 1$ & Sangat Valid \\
\hline & & (Retnawati, 2016:18)
\end{tabular}

Tabel 3: Kriteria Respon Peserta Didik

\begin{tabular}{ccc}
\hline No. & Rumus & Klasifikasi \\
\hline 1 & $\mathrm{X}>\bar{X}_{i}+1,8 \times \mathrm{xb}_{\mathrm{i}}$ & $\begin{array}{c}\text { Sangat } \\
\text { Baik }\end{array}$ \\
\hline 2 & $\overline{X i}+0,6 \mathrm{x} \mathrm{sb}_{\mathrm{i}}<\mathrm{X} \leq \overline{X_{i}}+1,8$ & Baik \\
& $\mathrm{x} \mathrm{sb}_{\mathrm{i}}$ & \\
\hline 3 & $\overline{X i}-0,6 \times \mathrm{sb}_{\mathrm{i}}<\mathrm{X} \leq \overline{X i}+0,6$ & Cukup \\
& $\mathrm{x} \mathrm{sb_{ \textrm {i } }}$ & \\
\hline 4 & $\overline{X_{i}}-1,8 \times \mathrm{xb}_{\mathrm{i}}<\mathrm{X} \leq \overline{X i}-0,6 \mathrm{x}$ & Kurang \\
& $\mathrm{sb}_{\mathrm{i}}$ & \\
\hline 5 & $\mathrm{X} \leq \bar{X}_{\imath}-1,8 \times \mathrm{xb}_{\mathrm{i}}$ & Sangat \\
\hline
\end{tabular}

Kurang

(Widoyoko, 2012:238)

\section{Hasil dan Pembahasan}

\section{Hasil Penelitian}

Penelitian ini merupakan penelitian pengembangan bahan pembelajaran (LKPD) Berbasis Etnosains dengan Model Penalaran Kausal untuk memecahkan masalah pada siswa SMPN 1 Pangkaje $\square$ ne kelas VIII D TA 2016/2017. Penelitian ini bertujuan untuk menghasilkan LKPD yang memenuhi kriteria valid, reliabel, dan efektif dengan menggunakan model pengembangan perangkat pembelajaran four-D melalui 4 tahapan define, design, develop dan dessiminate.

Berdasarkan indeks Aiken, hasil validitas LKPD untuk setiap aspek ditunjukkan pada tabel berikut:

Tabel 4: Hasil Validasi LKPD berbasis Etnosains dengan Model Penalaran Kausal untuk komponen penyajian

\begin{tabular}{c|c|c|c|}
\hline No. & Butir & $\sum \mathrm{s}$ & $\mathrm{V}$ \\
\hline 1. & Teknik Penyajian & 39 & 0,7 \\
\hline 2. & $\begin{array}{c}\text { Pendukung penyajian } \\
\text { materi }\end{array}$ & 66 & 0,7 \\
\hline & $\begin{array}{c}\text { Rerata Keseluruhan } \\
\text { Komponen Penyajian }\end{array}$ & 105 & 0,7 \\
\hline
\end{tabular}

Berdasarkan Tabel 4.3 diatas maka dapat ditunjukkan untuk aspek yang ada pada komponen pendukung penyajian materi yang diperoleh menggunakan indeks Aiken, nilai kevalidan untuk aspek teknik penyajian diperoleh nilai sebesar 0,7 ; dan pada butir pendukung penyajian materi diperoleh nilai sebesar 0,7 ; sehingga teknik penyajian dapat dikatakan valid.

Berdasarkan data diatas diperoleh rerata nilai $\mathrm{V}$ untuk komponen penyajian adalah 0,7 yang berarti LKPD dari segi keseluruhan komponen penyajian telah valid.

Tabel 5: Hasil Validasi LKPD berbasis Etnosains dengan Model Penalaran Kausal untuk komponen kelayakan isi 


\begin{tabular}{cccc} 
No. & Butir & $\sum \mathrm{s}$ & $\mathrm{V}$ \\
\hline 1. & Cakupan Materi & 29 & 0,7 \\
\hline 2. & Akurasi Materi & 38 & 0,7 \\
\hline 3. & Kemutakhiran & 29 & 0,7 \\
\hline 4. & Merangsang keingintahuan & 21 & 0,8 \\
\hline 5 & $\begin{array}{c}\text { Mengembangkan proses } \\
\text { keterampilan sains }\end{array}$ & 34 & 0,8 \\
\hline & $\begin{array}{c}\text { Rerata keseluruhan } \\
\text { komponen kelayakan isi }\end{array}$ & 151 & 0,7
\end{tabular}

Berdasarkan Tabel 4.4 diatas maka dapat ditunjukkan oleh 3 orang validator untuk semua aspek yang ada pada komponen kelayakan isi yang diperoleh menggunakan indeks Aiken, nilai kevalidan untuk aspek teknik kelayakan isi diperoleh nilai sebesar 0,7 sehingga teknik penyajian dapat dikatakan valid.

Berdasarkan Tabel 4 diatas maka dapat ditunjukkan untuk aspek yang ada pada komponen akurasi materi yang diperoleh menggunakan indeks Aiken, nilai kevalidan untuk akurasi materi diperoleh nilai sebesar 0,7 sehingga komponen akurasi materi dapat dikatakan valid.

Berdasarkan Tabel 4 diatas maka dapat ditunjukkan untuk aspek yang ada pada komponen kemutakhiran yang diperoleh menggunakan indeks Aiken, nilai kevalidan untuk aspek kemutakhiran diperoleh nilai sebesar 0,7 sehingga komponen kemutakhiran dapat dikatakan valid.

Berdasarkan Tabel 4 diatas maka dapat ditunjukkan untuk aspek yang ada pada komponen merangsang keingintahuan yang diperoleh menggunakan indeks Aiken, nilai kevalidan untuk aspek merangsang keingintahuan diperoleh nilai sebesar 0,8 sehingga komponen merangsang keingintahuan dapat dikatakan valid.

Berdasarkan Tabel 4 diatas maka dapat ditunjukkan untuk aspek yang ada pada komponen mengembangkan proses keterampilan sains yang diperoleh menggunakan indeks Aiken, nilai kevalidan untuk aspek mengembangkan proses keterampilan sains diperoleh nilai sebesar
0,8 sehingga mengembangkan proses keterampilan sains dapat dikatakan valid.

Berdasarkan data diatas diperoleh rerata nilai $\mathrm{V}$ untuk komponen kelayakan isi adalah 0,7 yang berarti LKPD dari segi keseluruhan komponen penyajian telah valid.

Tabel 6: Hasil Validasi LKPD berbasis Etnosains dengan Model Penalaran Kausal untuk komponen kebahasaan

\begin{tabular}{cccc} 
No. & Butir & $\sum \mathrm{s}$ & $\mathrm{V}$ \\
\hline 1 & $\begin{array}{c}\text { Sesuai dengan perkembangan } \\
\text { peserta didik }\end{array}$ & 12 & 0,6
\end{tabular}

\begin{tabular}{cccc}
\hline 2 & Komunikasi & 14 & 0,8 \\
\hline 3 & Dialog dan interaktif & 12 & 0,6 \\
\hline 4 & Lugas & 14 & 0,8 \\
\hline 5 & $\begin{array}{c}\text { Koherensi dan keruntutan } \\
\text { alur pikir }\end{array}$ & 14 & 0,8 \\
\hline 6 & $\begin{array}{c}\text { Penggunaan istilah dan } \\
\text { simbol lambang }\end{array}$ & 21 & 0,8 \\
& Rerata Keseluruhan \\
Komponen Kebahasaan & 87 & 0,7 \\
& &
\end{tabular}

Berdasarkan Tabel 6 diatas maka dapat ditunjukkan oleh 3 orang validator untuk semua aspek yang ada pada komponen sesuai dengan perkembangan peserta didik yang diperoleh menggunakan indeks Aiken, nilai kevalidan untuk aspek sesuai dengan perkembangan peserta didik diperoleh nilai sebesar 0,6 sehingga komponen sesuai dengan perkembangan peserta didik dapat dikatakan valid.

Berdasarkan Tabel 6 diatas maka dapat ditunjukkan untuk aspek yang ada pada komponen komunikasi yang diperoleh menggunakan indeks Aiken, nilai kevalidan untuk aspek komunikasi diperoleh nilai sebesar 0,8 sehingga komponen komunikasi dapat dikatakan valid.

Berdasarkan Tabel 6 diatas maka dapat ditunjukkan untuk aspek yang ada pada komponen dialog dan interaktif yang diperoleh menggunakan indeks Aiken, nilai kevalidan untuk aspek dialog dan interaktif diperoleh nilai sebesar 
0,6 sehingga komponen dialog dan interaktif dapat dikatakan valid.

Berdasarkan Tabel 6 diatas maka dapat ditunjukkan untuk aspek yang ada pada komponen lugas yang diperoleh menggunakan indeks Aiken, nilai kevalidan untuk aspek lugas diperoleh nilai sebesar 0,8 sehingga komponen lugas dapat dikatakan valid.

Berdasarkan Tabel 6 diatas maka dapat ditunjukkan untuk aspek yang ada pada komponen koherensi dan keruntutan alur pikir yang diperoleh menggunakan indeks Aiken, nilai kevalidan untuk aspek koherensi dan keruntutan alur pikir diperoleh nilai sebesar 0,8 sehingga komponen koherensi dan keruntutan alur pikir dapat dikatakan valid.

Berdasarkan Tabel 6 diatas maka dapat ditunjukkan untuk aspek yang ada pada komponen penggunaan istilah dan simbol yang diperoleh menggunakan indeks Aiken, nilai kevalidan untuk aspek penggunaan istilah dan simbol diperoleh nilai sebesar 0,8 sehingga komponen penggunaan istilah dan simbol dapat dikatakan valid.

Berdasarkan data diatas diperoleh rerata nilai $\mathrm{V}$ untuk komponen kelayakan isi adalah 0,7 yang berarti LKPD dari segi keseluruhan komponen kebahasaan telah valid.

Setelah produk di validasi oleh para ahli, maka LKPD diuji coba kepada siswa. Uji coba LKPD dilaksanakan oleh 34 siswa SMPN 1 Pangkaje $\square$ ne TA 2016/2017. Berdasarkan hasil tersebut maka dapat disimpulkan bahwa peserta didik SMPN 1 Pangkaje $\square$ ne memberikan tanggapan/respon yang sangat baik (sangat positif) terhadap LKPD Berbasis Etnosains dengan Model Penalaran Kausal.

Rekapitulasi data hasil angket/tanggapan peserta didik pada uji coba skala terbatas yang telah dikembangkan dapat dilihat pada gambar 2 :

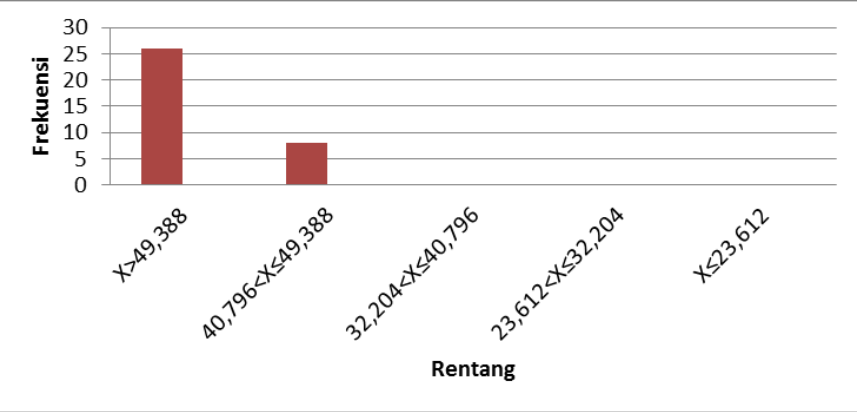

Gambar 2: Diagram Rekapitulasi data hasil angket respon peserta didik terhadap keseluruhan aspek LKPD.

Berdasarkan gambar 2 di atas maka dapat ditunjukkan gambaran respon peserta didik terhadap LKPD Berbasis Etnosains dengan Model Penalaran Kausal terdapat $76,5 \%$ dari jumlah siswa beranggapan sangat baik, 23,5\% dari jumlah siswa baik, sehingga diperoleh persentase respon peserta didik terhadap LKPD Berbasis Etnosains dengan Model Penalaran Kausal berjumlah $100 \%$. Berdasarkan hasil tersebut maka dapat disimpulkan bahwa peserta didik SMPN 1 Pangkaje $\square$ ne memberikan tanggapan/respon yang sangat baik (sangat positif) terhadap LKPD Berbasis Etnosains dengan Model Penalaran Kausal.

3) Analisis Keefektifan LKPD terhadap Hasil Belajar

a) Deskriptif Pretest

Tabel 7: Kategori Hasil Belajar Fisika Pretes

\begin{tabular}{cccc}
\hline $\begin{array}{c}\text { Rentang } \\
\text { Nilai }\end{array}$ & Frekuensi & Persentase(\%) & Kategori \\
\hline $0-34$ & 4 & 11,5 & $\begin{array}{c}\text { Sangat } \\
\text { Rendah }\end{array}$ \\
$35 \square 54$ & 10 & 28,5 & Rendah \\
$55 \square 64$ & 7 & 20 & Sedang \\
$65 \square 84$ & 12 & 34,2 & Tinggi \\
$85 \square$ & 2 & 5,7 & $\begin{array}{c}\text { Sangat } \\
\text { Tinggi }\end{array}$ \\
100 & 35 & 100 & \\
Jumlah & & &
\end{tabular}

Berdasarkan tabel 7 diatas maka dapat ditunjukkan kategori hasil belajar fisika pretes terhadap LKPD Berbasis Etnosains dengan Model 
Penalaran Kausal terdapat rentang 0-34 dari jumlah siswa beranggapan 4 peserta didik sangat baik dengan presentase $11,5 \%$, rentang $35-54$ dari jumlah siswa beranggapan 10 peserta didik baik dengan presentase $28,5 \%$, dari rentang 55-64 dari jumlah siswa beranggapan 7 peserta didik sedang dengan presentase $20 \%$, rentang $65-84$ dari jumlah siswa beranggapan 12 peserta didik baik dengan presentase 34,2\%,rentang 85-100 dari jumlah siswa beranggapan 2 peserta didik baik dengan presentase 5,7\%, Berdasarkan hasil tersebut maka dapat disimpulkan bahwa peserta didik SMPN 1 Pangkaje $\square$ ne memberikan hasil sebelum menggunakan LKPD Berbasis Etnosains dengan Model Penalaran Kausal berada pada kategori tinggi yaitu 12 peserta didik dengan presentase $34,2 \%$, maka digunakan LKPD untuk meningkatkan hasil belajar peserta didik setelah menggunakan LKPD.

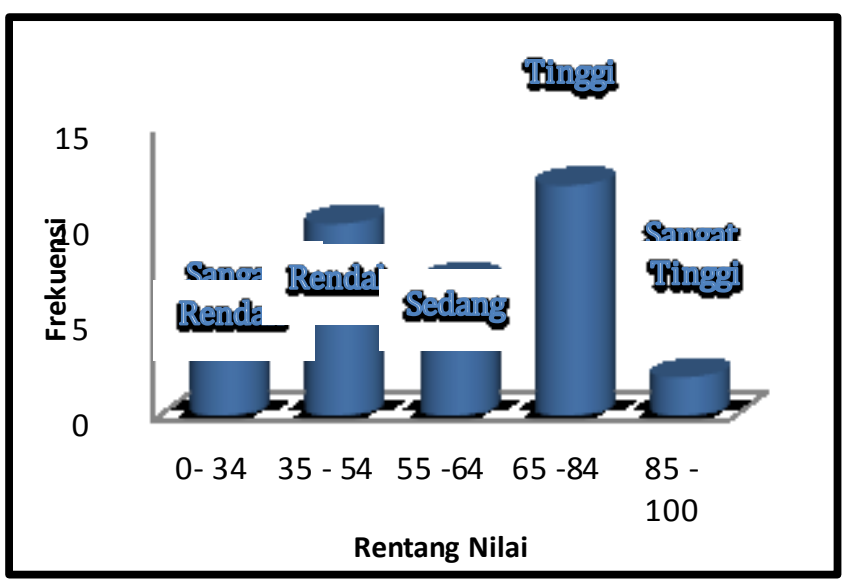

b) Deskriptif Postes

Tabel 8: Kategori Hasil Belajar Fisika Postes

\begin{tabular}{cccc}
\hline $\begin{array}{c}\text { Rentang } \\
\text { Nilai }\end{array}$ & Frekuensi & Persentase(\%) & Kategori \\
\hline $0-34$ & 1 & 2,9 & $\begin{array}{c}\text { Sangat } \\
\text { Rendah }\end{array}$ \\
$35 \square 54$ & 0 & 0 & Rendah \\
$55-64$ & 0 & 0 & Sedang \\
$65 \square 84$ & 18 & 51,4 & Tinggi \\
$85 \square$ & 16 & 45,7 & Sangat \\
\hline
\end{tabular}

$$
100
$$

Tinggi

Jumlah

35

$100 \%$

Berdasarkan tabel 8 diatas maka dapat ditunjukkan kategori hasil belajar fisika postes terhadap LKPD Berbasis Etnosains dengan Model Penalaran Kausal terdapat rentang 0-34 dari jumlah siswa beranggapan 1 peserta didik sangat rendah dengan presentase $0 \%$, rentang 35-54 dari jumlah siswa beranggapan 0 peserta didik baik dengan presentase 0\%, dari rentang 55-64 dari jumlah siswa beranggapan 0 peserta didik sedang dengan presentase $0 \%$, rentang 65-84 dari jumlah siswa beranggapan 18 peserta didik tinggi dengan presentase 51,4\%,rentang 85-100 dari jumlah siswa beranggapan 16 peserta didik sangat tinggi dengan presentase $45,7 \%$, Berdasarkan hasil tersebut maka dapat disimpulkan bahwa peserta didik SMPN 1 Pangkaje $\square$ ne memberikan hasil sebelum menggunakan LKPD Berbasis Etnosains dengan Model Penalaran Kausal berada pada kategori tinggi yaitu 12 peserta didik dengan presentase $34,2 \%$, maka setelah digunakan LKPD hasil belajar peserta didik meningkat dari frekuensi sebelumnya yaitu dari 12 peserta didik menjadi 18 peserta didik dengan presentase $34,2 \%$ meningkat $51,4 \%$ dan dari frekuensi sebelumnya yaitu dari 2 peserta didik menjadi 16 peserta didik dengan presentase 5,7\% meningkat $45,7 \%$ setelah menggunakan LKPD.

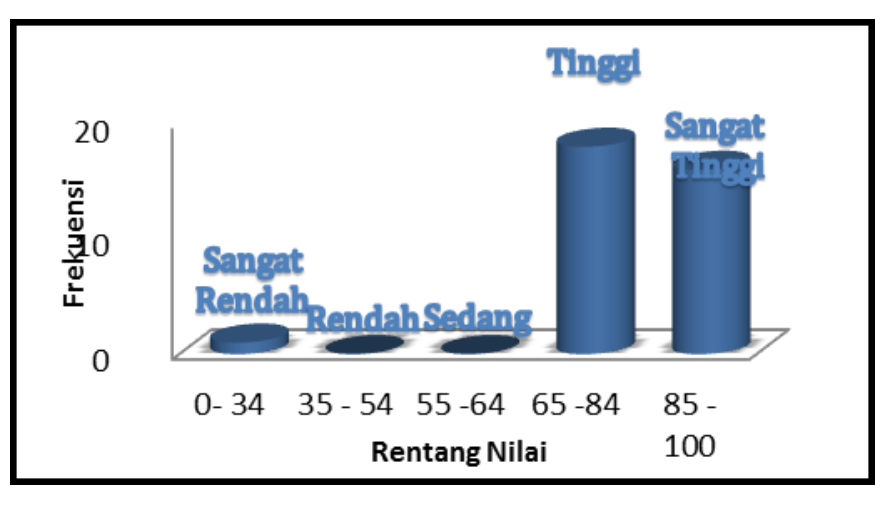

Gambar 4: Kategori Hasil Belajar Postes

c. Analisis Uji Signifikan keefektifan LKPD Berbasis Etnosains

Berdasarkan hasil analisis uji dalam Misbahuddin (2013 : 312) signifikan keefektifan yaitu:

Tabel 9: Kategori Uji Keefektifan LKPD 


\begin{tabular}{cccc}
\hline $\mathrm{T}_{\text {hitung }}$ & $\mathrm{T}_{\text {tabel }}$ & $\mathrm{X}_{\text {pretes }}$ & $\mathrm{X}_{\text {postes }}$ \\
\hline 5,02 & 2,03 & 56,02 & 82,71
\end{tabular}

Berdasarkan tabel 4.13 diatas menunjukkan kategori uji keefektifan LKPD Berbasis Etnosains dengan Model Penalaran Kausal diperoleh hasil thitung > 2,03 sehingga dapat dikatakan LKPD Berbasis Etnosains dengan Model Penalaran Kausal efektif dan dapat memecahkan masalah pada pada peserta didik.

\section{Pembahasan}

\section{Proses Pengembangan Lembar Kerja Peserta Didik Berbasis Etnosains dengan Model Penalaran Kausal.}

Sebelum membuat LKPD Berbasis etnosains banyak hal yang dilakukan yaitu; Produk awal LKPD Berbasis Etnosains (prototype I) yang dihasilkan kemudian dilakukan serangkaian uji untuk mendapatkan masukan serta saran yang membangun LKPD ini agar lebih baik lagi dan layak digunakan sebagai media pembelajaran. Uji tersebut menggunakan instrumen berupa lembar validasi ahli yang berisi aspek penyajian, kelayakan isi, serta kebahasaan. Baik buruknya instrumen akan berpengaruh terhadap benar tidaknya data yang diperoleh. Prototype II, instrumen yang baik harus memenuhi dua persyaratan yang penting yaitu validitas, reliabilitas serta keefektifan. Selama proses pengembangan perangkat pembelajaran terdapat beberapa catatan dari validator yang harus diperhatikan. Hasil dari lembar angket respon peserta didik terhadap LKPD diperoleh rata-rata peserta didik menunjukkan respon sangat baik terhadap produk. Setelah dilakukan validasi dan uji coba terhadap LKPD, maka didapatkan hasil dari tahap pengembangan yang disebut dengan prototype III. Sampai dengan tahap pengembangan. Berdasarkan hasil validasi dan angket respon peserta didik, maka diperoleh pendapat bahwa LKPD Berbasis Etnosains dapat diimplementasikan ke peserta didik berikutnya atau sekolah lainnya Tahap terakhir dari pengembangan LKPD adalah tahap penyebaran/dessiminate. Kegiatan ini tidak dilakukan karena keterbatasan peneliti untuk menyebarkan ke sekolah lain. Sehingga modul LKPD Berbasis Etnosains hanya disebarkan pada peserta didik di SMPN 1 Pangkaje $\square$ ne Kab. Pangkep.

\section{Bentuk LKPD Berbasis Etnosains degan Model Penalaran Kausal yang valid dan reliabel}

Secara umum hasil uji coba di lapangan untuk kriteria teknik penyajian telah memenuhi kriteria, komponen kelayakan isi dan komponen kebahasaan LKPD ditentukan oleh dua hal yaitu berdasarkan penilaian ahli (expert judgment) dan berdasarkan angket respon peserta didik. Berdasarkan hasil analisis validasi instrumen di atas diperoleh rata-rata valid. Rata-rata skor yang diberikan oleh 3 validator menyatakan bahwa LKPD Berbasis Etnosains dengan Model Penalaran Kausal untuk memecahkan masalah dapat digunakan. Sama halnya dengan kevalidan, untuk nilai $\mathrm{R}$ untuk setiap aspek pada ketiga komponen yaitu komponen penyajian, kelayakan isi, dan kebahasaan diperoleh rata-rata $\mathrm{R}>0,75$ sehingga dapat disimpulkan bahwa LKPD berbasis etnosains telah reliable atau dapat dipercaya. Penelitian yang dilakukan oleh Eren Fahrucah R dan Bambang Sugiarto Hal ini menunjukkan bahwa LKS dengan pendekatan scaffolding yang dikembangkan mempunyai penyajian, bahasa dan ketertarikan LKS memperoleh respon positif dengan persentase sebesar 93,05\% (sangat kuat) sehingga LKS dengan pendekatan scaffolding yang dikembangkan layak digunakan sebagai sumber pembelajaran berdasarkan respon siswa.

\section{Berdasarkan analisis hasil belajar peserta didik sebelum dan setelah menggunakan LKPD Berbasis Etnosains dengan Model Penalaran Kausal.}

Menggunakan uji signifikan keefektifan LKPD yang rata-rata nilai dari peserta didik meningkat dari pretes ke posttes dan dapat memecahkan masalah pada peserta didik serta dapat mengaitkan hal-hal yang ada didalam kehidupan sehari-hari, dapat dilihat dari $t_{\text {hitung }}>2,03$, sehingga LKPD Berbasis Etnosains dapat dikatakan efektif. Penelitian yang dilakukan Ima Ruhmawati, Dr. Ibrohim M.Si, Dra. Hj. Nursasi Handayani M.Si. Lembar kerja siswa kontekstual secara umum dapat meningkatkan hasil belajar siswa karena siswa merasa bahwa LKS 
kontekstual ini lebih menarik dibandingkan dengan LKS yang sebelumnya digunakan oleh siswa. Ketertarikan siswa terhadap LKS kontekstual dapat meningkatkan motivasi belajar siswa, sehingga dapat memicu siswa untuk lebih giat belajar. Hal inilah yang dapat menyebabkan siswa mendapatkan hasil belajar yang lebih baik dibandingkan pada saat siswa menggunakan LKS dari sekolah. Hasil penelitian ini juga didukung oleh beberapa penelitian sebelumnya.

\section{Kesimpulan}

1. Proses pengembangan modul LKPD berbasis etnosains dengan model penalaran kausal dengan prosedur pengembangan Research and Development (R\&D) dengan model tahapan 4D yaitu: (1) Define (Pendefinisian); (2) Design (Perancangan); (3) Develop (Pengembangan); (4) (4) Disseminate (Penyebaran).

2. Bentuk dari Lembar Kerja Peserta Didik (LKPD) Berbasis Etnosains dengan Model Penalaran Kausal menurut tiga pakar diperoleh nilai $\mathrm{V}$ yang diperoleh yaitu 0,7 sedangkan hasil penilaian untuk tingkat reliabilitas memperoleh nilai 0,89 dapat disimpulkan bahwa LKPD Berbasis Etnosains valid dan reliabel.

3. Respon/tanggapan dan hasil belajar peserta didik SMPN 1 Pangkaje $\square$ ne terhadap LKPD Berbasis Etnosains dikategorikan sangat baik (sangat positif), sedangkan setelah menggunakan LKPD Berbasis Etnosains dengan Model Penalaran Kausal rata-rata berada pada rentang kategori baik.

\section{Implikasi}

Implikasi penelitian pada skripsi ini adalah: (1) Disarankan kepada para guru untuk mengembangkan LKPD yang sesuai dengan kebutuhan peserta didik dengan berbasis dan model yang lain. (2) LKPD yang dikembangkan dapat dibuat semenarik mungkin dan diberi informasi mengenai penerapan materi dalam kehidupan sehari-hari. (3) Model yang digunakan dalam mengembangkan LKPD harus sesuai dengan materi pembelajaran dan materi Etnosains.

\section{Daftar Pustaka}

Djanji, Purwanto, 2014, Pengembangan Perangkat Pembelajaran, Gaya Media, Yogyakarta.

Kumaidi, 2014. Pengantar Metode Statistik: Teori dan Terapanny dalam Penelitian Bidang Pendidikan dan Psikologi. Eduvision, Cirebon.

Misbahuddin, 2013. Data Penelitian dengan Statistik edisi Kedua, PT. Bumi Aksara, Jakarta.

Retnawati, Heri. Validitas reliabilitas dan karakteristik butir (Panduan untuk Peneliti, Mahasiswa, dan Psikometrian), 2016, Parama Publishing, Yogyakarta.

Trianto, 2011. Mendesain Model Pembelajaran Inovatif-Progresif. Konsep, Landasan, dan Implementasinya pada KurikulumTingkat Satuan Pendidikan (KTSP). Cet. V; Jakarta: Kencana.

Utami, Anisa, 2015, Pengembangan Modul Pembelajaran Sanitasi, Hygiene Dan Keselamatan Kerja Di Sekolah Menegah Kejuruan Negeri 3 Wonosari, skripsi, UNY, Yogyakarta.

Widyoko, Eko Putro, 2012. Evaluasi Program Pembelajaran Panduan Praktis bagi Pendidik dan Calon Pendidik. Pustaka Pelajar. Jakarta. 